\title{
THE INNOVATION OF MODERN ISLAMIC EDUCATION SYSTEM BASED ON PROGRESSIVE BOARDING SCHOOL IN MADRASAH TSANAWIYAH NEGERI 1 BIMA
}

\author{
Suherman ${ }^{1}$ Mahsun Jayadi ${ }^{2}$ \\ suhermanbima1234@gmail.com ${ }^{1}$ mahsun_umsby@gmail.com²
}

\begin{abstract}
The purpose of this research is to find out the implementation of the innovation of modern Islamic education system based on the progressive boarding school in Madrasah Tsanawiyah Negeri 1 Bima which is able to produce a new approach that can accommodate all the development of spiritual, emotional, intellectual and social students. Innovation of modern Islamic education system based on boarding school become an alternative strategy of PAI learning which able to give hope in teaching moral value for learners. This research is a qualitative descriptive, using sociological phenomenology approach. The result of this research shows that the innovation of the Islamic education system in the Madrasah Tsanawiyah Negeri 1 Bima comes from a fundamental thought and contains a meaningful reconstruction of the nation for the realization of the ideals of the developed, equitable, prosperous, dignified, and sovereign state parallel to other nations and countries that have achieved excellence progressing in the spirit, mindset, behavior and always future oriented to realize better conditions as a result of an innovation.
\end{abstract}

Keywords: Innovation in Education, Islamic Education, Boarding School

\section{A. Introduction}

As a response of the various concerns of parents about the future of their children's education, it needs innovation in the educational system, especially Islamic educational institutions. Nowadays, there are many modern educational system that became an interesting phenomenon in the educational system in Indonesia. These are the emergence of integrated schools ranging from elementary to middle level, and the higher quality schools are often called as full day and boarding school. The emergence of full-day school schools and boarding school since the mid-1990s as the result of the condition of the educational system in Indonesia which has not met the ideal expectations. Physically, conventional school is now clearly existed but conceptually, it is no longer adequate to accommodate the aspirations of some communities.
Thus, an innovation in the educational system in form of boarding school with comprehensive-holistic educational pattern makes it possible to create an ideal educational environment in order to create the nation as a motor of social, political, economic and religious life in the future.

Education with the boarding school system is expected to effectively educate the intelligence, skills, character building, moral values, religious values, and honesty. So, students have a perfect and distinct personality. ${ }^{1}$

The advantage of the boarding school system is that students can be monitored by teachers and mentors for 24 hours. Moreover, educational services and guidance in boarding school system is done freely and holistically. All student activities will always be guided, and the closeness relationship between students and

\footnotetext{
${ }^{1}$ Kholid Musyaddad, Kepemimpinan Berbasis Nilai dan Pengembangan Mutu Madrasah, (Bandung: Alfabeta, 2012), 10.
} 
teachers are always kept so problems occurred by students can be resolved as quickly as possible. $^{2}$

Madrasah Tsanawiyah Negeri (State junior high school) which has innovated the education system by applying the boarding school system in Bima is Madrasah Tsanawiyah Negeri 1 Bima. By applying the Boarding School program, it is expected to make the madrasah as a place of character and morality education of learners in holistic, integrated, and balanced in accordance with the competency standards of graduates and expectations of the parents and the nation.

In the 21st century, competitiveness will be a major indicator for schools or madrasah to compete to get students' and parents' attentions. Competitiveness will grow in line with the outputs generated by schools or madrasah of good quality from public and private schools that have the advantage and progress. Basically, all parents want their children to be accepted to a high quality or favorite school. A favorite school, according to their perspective, is a school that can fulfill the emotional needs of the children as well as the parents both intellectually and affectively in public and private schools.

From the results of observations, it shows that conventional schools are considered inadequate to form the personality of students, the personality of Islam and nationalism completely. It is because conventional schools only provides for 7-8 hours in a day for learning process. In addition, conventional schools are more intellectual and more oriented on theoretical mastery while the affective

${ }^{2}$ Sutrisno, Problem dan Solusi Pendidikan Sekolah Berasrama (Boarding School), aspects that are not less important in education for the formation of Islamic personalities are often neglected.

In the perspective of educational idealism, it seems that boarding school is promising to overcome the learning backwardness in cognitive, psychomotor, and affective domains. Islamic education is criticized because of the available time limitations which has an impact on the material and internalization of the Islamic values. Therefore, the ideology of nationalism dominates minds of the students.

The combination of madrasah with a boarding school system combines formal education and a dormitory system to support the school vision of generating the Islamic generation of kaffah. The Innovation is done in several learning aspects which is a routine intra-curricular program for all learners because the school has set targets to be achieved by learners during the educational process in MTs Negeri 1 Bima.

There are many innovation programs of modern boarding school system conducted in MTs Negeri 1 Bima such as: Tahfizul Qur'an, memorizing 100 Hadits BuhariMuslim, Tafsir Hadith, Arabic language development, and English language development. Furthermore, there is a program of Qur'an memorizing target as a requirement for students who want to rise their grade as follows: from grade VII to grade VIII is $30^{\text {th }} j u z$ required, from grade VIII to grade IX is $29^{\text {th }} j u z$ required. Meanwhile, to take the final national examination, students must complete the memorization of $29^{\text {th }} j u z$ and $30^{\text {th }}$ juz plus an optional $j u z, 28^{\text {th }}$ or $1^{\text {st }}$.

Human resources with competitive advantages will be owned if the human

http://sutris02.wordpres.com/ accessed on October, 15 2017, on 11 a.m. 
resources of Indonesia are able to master science and technology. Therefore, education at MTs Negeri 1 Bima is also developing various knowledge including science, Indonesian, mathematics, natural science, social science, ICT and so on.

In addition, the school already has facilities with complete laboratory for each subject. Schools as the main source for the development of superior human resources must be able to respond to the demands of the global era so the future of the nation and the state of Indonesia is not left behind and crushed by other nations and countries.

Besides the enhancement and development of the science and technology mastery, the insights of modern Indonesian human resources must remain diminished in sensitivity to national and religious norms. It is intended that Indonesian human resources do not lose their identity as a moral and religious nation. Modern Islamic education based on boarding school leading to a progressive school presents the figure of educational institutions awaited by many people because it is able to show an innovation of the right educational system in the era of national moral decline of the children.

Innovation of Islamic boarding school based education system done in MTs Negeri 1 Bima has not been done in other state schools in Bima at Madrasah Tsanawiyah (MTs) or Junior High School (SMP) level. MTs Negeri 1 Bima is a school developed to achieve excellence in education as a model in order to improve the quality of education. Learning facilities and infrastructures to support learning activities in modern schools are

3 Ainur Raziq AR., Mengajar Madrasah Unggulan Yang Murah, (Surabaya: Mimbar No.229, 2005), 38. generally more complete than that in non-superior schools. Likewise with the method of learning, using methods equipped with a variety of props from the manual up to use Information Technology (IT) to facilitate the students learning process. In addition, the educators/teachers are mostly professional and qualified. Thus, it is expected that students are able to absorb the learning material perfectly.

Of the several advantages of the schools, it cannot be denied that every parent wants their children to be a superior man. This can be seen from the public interest to enroll their children into the leading schools as in MTs Negeri 1 Bima. Every new academic year is flooded with prospective students because they belief that the schools can produce superior humans. In these conditions, eventually educational institutions should seek a variety of information and alternatives to be able to meet the demands and expectations of society in the qualified, satisfied and advantageous education.

Efforts to improve the quality of education are pursued by establishing modern schools with boarding school system, because modern schools are seen as an effective alternative to show its contribution in improving the quality of education through innovation of educational system, especially in the aspect of religion. ${ }^{3}$

Mochtar Buchori states that religious education activities implemented recently is more solitary, less interaction with other educational activities. This ways is less effective for the purpose of teaching complex value devices. Therefore, the teachers/ religious educators need to work together with non-religious teachers if 
they want to have relevance to the social changes that occur in society ${ }^{4}$

The challenge of Islamic education is also related to the challenge of education in Indonesia in general, especially in improving Indonesian human resources. Various challenges facing by education in general also must be faced by religious education as part of the national education process. If the educational aspect in Indonesia determines the various innovations to keep optimally functioning in the changeable era, then religious education must also determine the various innovations so its existence remains meaningful for the life of the nation.

From the above description, it can be understood that religious education is not only concerned with the transformation of the teachings and its value to others, but rather a complex problem. For example: the approach still tends to be normative in the sense of religious education presenting norms without context illustration of social culture so learners less appreciate the values of religion. Islamic education curriculum designed schools has minimal information so the spirit to enrich the curriculum with learning experience is growing slowly. Professional teachers are less trying to explore methods used for religious education, and having limited facilities/ infrastructure.

In line with the perspective and ideals above, the school should change the attitude of the old view, the view that Islamic educational institutions only as a warehouse of science/ bank transfer and cultural transmission into a central processing of natural and scientific science that refers to the demands community. Thus, the desired learning style is an innovative learning rather than learning to preserve the exist thing (maintenance learning), conservative, passive and dogmatic.

The consequences of the view of optimism is that the school must be managed systematically in accordance with the strategy of fostering the generation of the nation that is able to create a complete Indonesian man. Religious education programs must be reorganized to anticipate the moral needs of the nation in modernism. As the response to the development of educational institutions in the model of "Modern Schools", the school especially the school principal (Visionary Leadership) arises awareness to renew the system of religious education and learning process in the school.

Seeing the importance of education as the main capital of the creation of qualified human resources, the understanding in all aspects of education should be implemented immediately, especially religious education. Why is that? Because religious education is one of the main strengths in realizing a qualified generation. Religious education is an education that must be owned by every student, because religious education will be the director for other education. Mastery of science and technology without accompanied by the mastery of religious science will certainly cause a lot of disharmony in life.

Madrasah Tsanawiyah Negeri 1 Bima, in this case, is one of the madrasah/ educational institutions combined with the boarding school system which is considered to be a reference and the choice of people in Bima nowadays especially for families who are able to pay for their children's

\footnotetext{
${ }^{4}$ Muhaimin, et.al, Paradigma Pendidikan Islam, (Bandung: Remaja Rosdakarya, 2004), 89.
} 
education because the quality of the education in this school is undoubtedly.

\section{B. Research Methods}

This is a qualitative research. According to Lexy J. Moleong, qualitative research is: "Research that intends to understand the phenomenon of what is experienced by research subjects such as behavior, perception, motivation, and ction holistically by describing it in the form of words and language, in a specific, natural context and by utilizing various methods". 5

The type of this research is descriptive research. According to Prof. Dr. Winarmo Surachmad, in his book "research methodology and research introduction", states that descriptive research is a study that attempts to describe existing problemsolving based on facts, as well as providing, analyzing and interpreting the data. ${ }^{6}$

The reason of using descriptive qualitative approach in this research is because in this research the data generated in the form of descriptive data obtained from facts in the form of written/ oral and behavior observed derived from sources or informants that can be researched and trusted without questioning the relationship between research variables.

Qualitative data analysis, according to Bogdan and Biklen cited by Lexy $\mathrm{J}$. Moleong, is an effort done by working with data, organizing data, sorting it into manageable units, populating it, searching and finding patterns, finding what is important and

\footnotetext{
${ }^{5}$ Lexy J. Moleong, Metodologi Penelitian Kualitatif, (Bandung: Remaja Rosdakarya, 2007), 6.

${ }^{6}$ Cholid, Narbuko dan Abu Ahmadi, Metodologi Penelitian, (Jakarta: Bumi Aksara,) 2005), 44.
}

what which is learned and decides what can be told to others. ${ }^{7}$

\section{Results and Discussion}

Innovation of Islamic education system based on boarding school model in this research is an innovation to solve educational problems and answer the needs of various concerns of parents and community about their children's educational future. This needs an innovation of excellent Islamic education system especially in institutions Islamic education of Madrasah. Innovation in this case includes matters relating to the components of the educational system that previously do not respond to the public demand on the quality of output products produced by the school to the reliable output in competing the next better education level.

The typical innovations conducted at MTs Negeri 1 Bima, related to the aspect of educational objectives are curriculum, and the addition of boarding school education system that is expected to effectively educate the intelligence, skills, character building and the cultivation of moral and religious values of students. So, students have an Islamic personality in lined with expectations of parents, society, educational institutions, and nations symbolized with the phrase "having the brain of German, the heart of Mecca, and the spirit of Japan".

The system innovation should be able to integrate two important components, namely faith and piety (imtak) with science and technology and art (Science). Therefore, the

\footnotetext{
${ }^{7}$ Lexy J. Moleong, Metodologi Penelitian Kualitatif, 248.
} 
combination these component was the insight of "Ulul Albab" who remember the greatness of God and the creation of the heavens and the earth. Thus, it is natural that God will raise the degree of unity of Imtak and Science. As the word of Allah SWT: Meaning: "... Allah will raise (degree) those who believe in Allah among you and those who are given insight in a few degrees. And Allah know what you do."

Believed and pious scholars (Imtak) with science and technology and art (science) are the future assets of the nation as well as the parents of the world and the hereafter because they have a superior character and a strong Islamic spirit that can provide examples and role model for the surrounding community. If this is not supported with a clear educational innovation, the failure of this nation is getting worse because it is led by a leader with bad character, far from the values of honesty and religious norms.

The main objective of the innovation of modern Islamic educational system based on progressive boarding schools is to promote values education, character education, moral education aimed to develop students' ability to decide whether good-bad, obligatory-sunnah, halal-kharam, manifest and spread goodness in daily life with full faith according to Al-Qur'an and As-Sunnah (hadith), as to become human with a noble akhlaq rahmatan lil'alamain, as explained in word of Allah SWT: It means: "And we do not send thee (Muhammad) but to be a mercy to all the world."

The purpose of the innovation of Islamic educational system based on the progressive boarding school is in lined with the progress and demands of the era as follows: First, the catch-up of science and technology advances so education runs parallel to the progress of the era without ignoring the faith education and piety. Second, as an effort for the implementation of boarding school education as a place of teaching Islamic personality and morality of students. Third, making boarding school education as a wall to decline crime rates and delinquency that often occur among students such as fighting among students, and the use of drugs.

In its development, boarding school has a lot of interest and the number is increasing along with the increasing public interest to send their sons and daughters to boarding schools. The increasing number of santri (students' of boarding school) makes it impossible to accommodate all. This indicates that the innovation of modern Islamic education system based on the progressive of boarding school is very appropriate to be developed in Islamic secondary schools both junior and high school levels.

The result of the interview with Salahuddin, S.Ag, said that before the innovation of modern Islamic education system based on boarding school, students MTs Negeri 1 Bima have difficulties to pass the enrollment selection of new students in the famous and favorite schools in Indonesia. After the innovation of Islamic education system based on progressive boarding school, most the alumnus of the boarding house in MTs Negeri 1 Bima have a very good chance in continuing their education in favorite and famous higher school that has a high standard in the selection of new students acceptance such as "Mu'allimin/

\footnotetext{
${ }^{9}$ See, Qur'an Surah Al-Anbiya, (21), 107.
} 
Mu'allimat" in Yogyakarta, "Daarul Qolam" in Tangerang, and "Abu Hurairah" in Mataram.

One of the principles of curriculum development in MTs Negeri 1 Bima is a sociological principle. This principles imply that the curriculum must give attention to the demands of society needs. This is reinforced by the results of research from the interview with one of the parents of MTs Negeri 1 Bima student, namely Kasianto.

The results of interviews with parents, Kasianto, is that before the innovation of Islamic education system based on boarding school, curriculum applied in MTs Negeri 1 Bima is less to touch the life needs of students in the social environment of society or the real condition of student life. This statement is based on the comparison of his two children who study in MTs Negeri 1 Bima, where his first child only attends regular education of madrasah (school), while his second child attends regular education and boarding school. There is a quite visible difference from his two children in terms of insight and obedience in worship (prayer), where the second child is better than his first child.

Innovation on curriculum and learning can be interpreted as ideas, or specific actions in the field of curriculum and learning that are considered new ways to solve educational problems. The curriculum must be able to answer the needs of students in the future. Education not only serves to preserve the culture of the past, but also to prepare students in order to live and adjust to the demands of the era. Therefore, the innovation of the educational system given to the school must be tested and have value for the life of the students in the future.
The result of interview with teacher of Aqeeda Akhlaq subject, Najmah, S.Pd.I, as well as the person in charge of grade VIII B, states that before the innovation of Islamic education system based on boarding school, the level of students' politeness and respect to teachers is still lower than after the innovation of Islamic boarding school education system applied. Students stayed in boarding school are familiarized with an Islamic life under the guidance and coaching performed in the dormitories. Students are the main targets that need attention to change because all the educational process implemented leads to the achievement of comprehensive changes in students either cognitive, psychomotor, or affective.

The result of an interview with Suhardin, S.Pd.I, a boarding school guide, states that before the innovation of the boarding school based Islamic education system is applied, the students' communication ability using Arabic and English as well as the Qur'an recitation ability are very minimum. However, after the innovation implemented, student responses are quite high because Arabic and English are always used in the dormitory, while the recitation of their Qur'an is graduated with 3 juz memorization. In the case of prayers together, before the innovation implementation only a small part of the students joined the dhuhur prayers in jama'ah (together) because it is limited by inadequate Musholla space, but after the innovation done, a mosque is built and students are not allowed to go home before they praying Dhuhur in jama'ah (together).

Islamic boarding school based education system has many advantages as follows: students can learn more maximal, focus, can directly interact 
with teachers, and activities are always controlled in the dorm. Another benefit is that students can learn independently in the school environment. Good examples can be seen directly in their environment without delay. Thus, the boarding school education system provides a characteristic that is able to combine the cognitive, psychomotor, and affective education of students so they can be trained better and optimally.

One of the best ways to teach the affective aspect is by providing examples from teachers and mentors and influencing people around students. By letting students stay in boarding house in 24 hours, students not only get cognitive lessons but also can directly see how the behavior of teachers, and people who teach them. Students can directly see, even follow imam (leader), how to pray solemnly, for example. It is very different from the prayer lesson, without any examples and experience to the imam who prayed solemnly.

The boarding school system is able to optimize the students' cognitive, affective, and psychomotor domains. This system has teachers and school managers ready to commit for 24 hours, day and night, conducting learning process both teaching sciences and giving example of knowledge practices.

Another advantages of this system are the boarding system more emphasizes on self-reliance education (independence) and trying to avoid the scientific dichotomy (the science of religion and general science). With learning that integrates the science of religion and general science, it is expected to form a whole personality of each student. Educational services and guidance with the boarding school system in 24 hours give more freely and comprehensive learning scheduling. All student activities will always be guided and the closeness relationship between teachers and students is always kept. Students' problems will always be known and immediately resolved. Moreover, the principle of teacher modeling will always be applied because the students know every teacher activity in 24 hours.

\section{Conclusions}

The result of the research indicates that: (1) Innovation of modern Islamic education system in Madrasah Tsanawiyah Negeri 1 Bima comes from a fundamental thinking and contains a meaningful reconstruction of nationalism to realize of the idea of modern, equitable, prosperous, and independent nation in line with other nations and countries that have achieved excellence of spirit, mindset, behavior and future oriented to realize better life as a result of an innovation.

(2) The modern Islamic educational system has several dimensions. First, progress in spirit, mindset, behavior, and always have future oriented. Second, progress to realize better life, in material and spiritual. Third, progress to make modern education in various fields as a result of an innovation.

\section{References:}

Kholid Musyaddad, Kepemimpinan Berbasis Nilai dan Pengembangan Mutu Madrasah, Bandung: Alfabeta, 2012.

Sutrisno, Problem dan Solusi Pendidikan Sekolah Berasrama Boarding School, http://sutris02.wordpres.com/.

Ainur Raziq AR., Mengajar Madrasah Unggulan Yang Murah, 
(Surabaya: Mimbar No.229, 2005), 38.

Muhaimin, Paradigma Pendidikan Islam, Bandung: Remaja Rosdakarya, 2004.
Lexy J. Moleong, Metodologi Penelitian Kualitatif, Bandung: Remaja Rosdakarya, 2007.

Cholid, Narbuko dan Abu Ahmadi, Metodologi Penelitian, Jakarta: Bumi Aksara. 